\title{
Autonomic Hyperactivity in Patients with Vasospastic Angina
}

\author{
Kazuhiko Tamada, M.D., Yoshihisa Ito, M.D., \\ and Hisashi Fukuzaki, M.D.
}

\section{SUMmARY}

To evaluate the role of the autonomic nervous system in vasospastic angina, plasma catecholamine and cyclic nucleotide levels were measured and the pilocarpine test was performed in 19 patients with vasospastic angina, 14 patients with nonvasospastic angina and 7 control subjects who were hospitalized patients without heart disease. Diurnal and nocturnal levels of plasma catecholamines were significantly higher in patients with angina pectoris, especially in patients with vasospastic angina, as compared with those of controls. In addition, an increase in plasma catecholamines preceded the onset of spontaneous and pilocarpine induced anginal attacks associated with significant increases in plasma catecholamines in patients with vasospastic angina. On the other hand, while nifedipine significantly suppressed both spontaneous and pilocarpine induced anginal attacks, the increase in plasma catecholamines remained.

These results indicate that increased activity and responsiveness of the sympathetic nervous system may possibly contribute to the development of vasospastic angina on the basis of parasympathetic hyperactivity.

\section{Additional Indexing Words:}

Vasospastic angina

Plasma catecholamine
Pilocarpine Sympathetic activity

Plasma cyclic nucleotides

$\mathrm{I}^{\mathrm{N}}$ 1974, Yasue postulated that spasm of the epicardial coronary arteries might be induced by stimulating the $\alpha$-adrenergic receptors and that hyperactivity of the parasympathetic nervous system might be involved in the initiation of vasospastic angina." Furthermore, recent reports of physiologic and pharmacologic stimuli such as the cold pressor and methacholine

From the Department of Internal Medicine, Division I, Kobe University School of Medicine, Kobe, Japan.

Address for reprint: Kazuhiko Tamada, M.D., Department of Internal Medicine, Division I, Kobe University School of Medicine, 5-2, 7-chome, Kusunoki-cho, Chuo-ku, Kobe 650, Japan.

Received for publication October 25, 1984.

Manuscript revised February 12, 1985. 
tests have suggested that underlying autonomic dysfunction may be a cause of vasospastic angina. ${ }^{1-3)}$ On the other hand, however, Clark reported that the angiographic demonstration of occlusive coronary spasm remained in vasospastic patients with cardiac denervation secondary to autotransplantation and stripping of the great vessels. ${ }^{4}$ ) Thus, the role of the autonomic nervous system in vasospastic angina is still controversial. This study was performed to evaluate the pathophysiological significance of the autonomic nervous system in vasospastic angina and included a biochemical assessment of sympathetic nerve activity by measuring plasma norepinephrine, epinephrine and cyclic AMP, and of parasympathetic nerve activity by measuring plasma cyclic GMP.

\section{Materials and Methods}

The study was performed in 33 patients ( 31 males and 2 females) with angina pectoris with a mean age of $53.9 \pm 1.5$ years and 7 control subjects without heart disease, with a mean age of $52.1 \pm 3.5$ years. Nineteen patients were defined as having vasospastic angina with angiographically documented coronary artery spasm provoked by ergonovine malate and/or ST-segment elevation of $0.2 \mathrm{mV}$ or more measured at the point $0.08 \mathrm{sec}$ from the $\mathrm{J}$ point on ECG during anginal episodes. The remaining 14 patients with nonvasospastic angina had effort and/or rest angina pectoris. Circadian variations of plasma catecholamines and cyclic nucleotides were determined every 4 hours in 24 patients with angina pectoris including both vasospastic and nonvasospastic angina, and in 5 control subjects. Blood samples were withdrawn from the antecubital vein through an indwelling scalp needle after the patients had rested in the supine position for $30 \mathrm{~min}$. Plasma norepinephrine and epinephrine were determined using a highly sensitive and specific electrochemical detector combined with high performance liquid chromatography (HPLC) (VMD-101, Yanagimoto Co.) after purification with alumina (Merck Co.).5) Cyclic nucleotides were measured by radioimmunoassay after saccinylation. ${ }^{6}$ ) The pilocarpine test started at 10 a.m., when a $1 \%$ solution of pilocarpine hydrochloride was injected subcutaneously at a dose of $1.3 \mathrm{mg} / 10 \mathrm{Kg}$ body weight. EGG, blood pressure and cardiac rate were recorded, and symptoms such as sweating, salivation and chest pain were monitored. When the patients noticed chest pain and/or ischemic ECG changes were noted, nitroglycerin was administered sublingually. Informed consent was obtained in all patients.

Data are expressed as the mean \pm SEM. Clinical data were compared using unpaired and paired t-tests. When more than 2 groups were compared, 
analysis of variance was used. A probability $p$ value of $<0.05$ was considered statistically significant.

\section{Results}

Coronary angiography was performed in 19 cases with vasospastic angina and 14 cases with nonvasospastic angina. In the vasospastic group, 12 cases had single vessel disease, 6 cases had normal coronary arteries and the remaining 1 case had two vessel disease. In the nonvasospastic group, 8 cases had single vessel disease, 4 cases two vessel disease and 2 cases three vessel disease.

1. Circadian variation of plasma catecholamines

Plasma catecholamine concentrations were measured every 4 hours in 24 patients with angina pectoris including 12 with vasospastic and 12 with nonvasospastic angina and 5 control subjects. Control subjects showed higher plasma catecholamine levels at arousal time and lower levels during sleep. The angina group had higher plasma catecholamine levels at all check points when compared with the control subjects. In particular, the vasospastic group had significantly higher plasma norepinephrine concentrations at midnight, noon, 4 and 8 p.m. Plasma epinephrine concentrations were significantly higher at $4 \mathrm{a} . \mathrm{m}$. and noon in the vasospastic group. In

Table I. Circadian Variation of Plasma Catecholamine Concentration in Control Subjects and Patients with Angina Pectoris

Plasma norepinephrine concentration $(\mathrm{pg} / \mathrm{ml})$

\begin{tabular}{c|c|c|c|c|c|c}
\hline Time (hour) & $0: 00$ & $4: 00$ & $8: 00$ & $12: 00$ & $16: 00$ & $20: 00$ \\
\hline $\begin{array}{c}\text { Control subjects } \\
(\mathrm{n}=5)\end{array}$ & $\begin{array}{r}116.9 \\
\pm 17.9\end{array}$ & $\begin{array}{r}134.8 \\
\pm 15.9\end{array}$ & $\begin{array}{r}179.0 \\
\pm 17.1\end{array}$ & $\begin{array}{r}173.8 \\
\pm 15.6\end{array}$ & $\begin{array}{r}181.9 \\
\pm 25.3\end{array}$ & $\begin{array}{r}165.9 \\
\pm 21.6\end{array}$ \\
\hline $\begin{array}{c}\text { Vasospastic angina } \\
(\mathrm{n}=12)\end{array}$ & $\begin{array}{c}196.3 \\
\pm 17.2^{* *}\end{array}$ & $\begin{array}{r}196.4 \\
\pm 23.9\end{array}$ & $\begin{array}{r}217.8 \\
\pm 19.7\end{array}$ & $\begin{array}{r}302.0 \\
\pm 36.0 *\end{array}$ & $\begin{array}{r}309.2 \\
\pm 35.7 *\end{array}$ & $\begin{array}{c}272.9 \\
\pm 28.9^{*}\end{array}$ \\
\hline $\begin{array}{c}\text { Nonvasospastic angina } \\
(\mathrm{n}=12)\end{array}$ & $\begin{array}{c}168.8 \\
\pm 11.9 *\end{array}$ & $\begin{array}{r}172.3 \\
\pm 16.8\end{array}$ & $\begin{array}{r}211.1 \\
\pm 19.6\end{array}$ & $\begin{array}{r}244.9 \\
\pm 26.7\end{array}$ & $\begin{array}{r}229.1 \\
\pm 17.7\end{array}$ & $\begin{array}{r}213.8 \\
\pm 21.2\end{array}$
\end{tabular}

Plasma epinephrine concentration $(\mathrm{pg} / \mathrm{ml})$

\begin{tabular}{c|r|r|r|r|r|r}
\hline Time (hour) & $0: 00$ & $4: 00$ & $8: 00$ & $12: 00$ & $16: 00$ & $20: 00$ \\
\hline $\begin{array}{c}\text { Control subjects } \\
(\mathrm{n}=5)\end{array}$ & $\begin{array}{r}80.5 \\
\pm 17.5\end{array}$ & $\begin{array}{r}64.1 \\
\pm 16.1\end{array}$ & $\begin{array}{r}122.7 \\
\pm 24.4\end{array}$ & $\begin{array}{r}88.7 \\
\pm 15.1\end{array}$ & $\begin{array}{r}128.8 \\
\pm 30.2\end{array}$ & $\begin{array}{r}104.3 \\
\pm 37.8\end{array}$ \\
\hline $\begin{aligned} \text { Vasospastic angina } \\
(\mathrm{n}=12)\end{aligned}$ & $\begin{array}{r}118.2 \\
\pm 20.3\end{array}$ & $\begin{array}{r}122.7 \\
\pm 15.3 *\end{array}$ & $\begin{array}{r}123.9 \\
\pm 14.8\end{array}$ & $\begin{array}{r}157.9 \\
\pm 13.9 * * *\end{array}$ & $\begin{array}{r}181.2 \\
\pm 30.4\end{array}$ & $\begin{array}{r}156.2 \\
\pm 28.6\end{array}$ \\
\hline $\begin{array}{c}\text { Nonvasospastic angina } \\
(\mathrm{n}=12)\end{array}$ & $\begin{array}{r}99.9 \\
\pm 16.5\end{array}$ & $\begin{array}{r}91.5 \\
\pm 18.4\end{array}$ & $\begin{array}{r}122.4 \\
\pm 18.9\end{array}$ & $\begin{array}{r}137.9 \\
\pm 22.9\end{array}$ & $\begin{array}{r}152.5 \\
\pm 25.6\end{array}$ & $\begin{array}{r}137.6 \\
\pm 21.4\end{array}$
\end{tabular}

Values are given as mean \pm 1 SEM. ${ }^{* * *} \mathrm{p}<0.01, * * \mathrm{p}<0.02, * \mathrm{p}<0.05$ vs control subjects. 


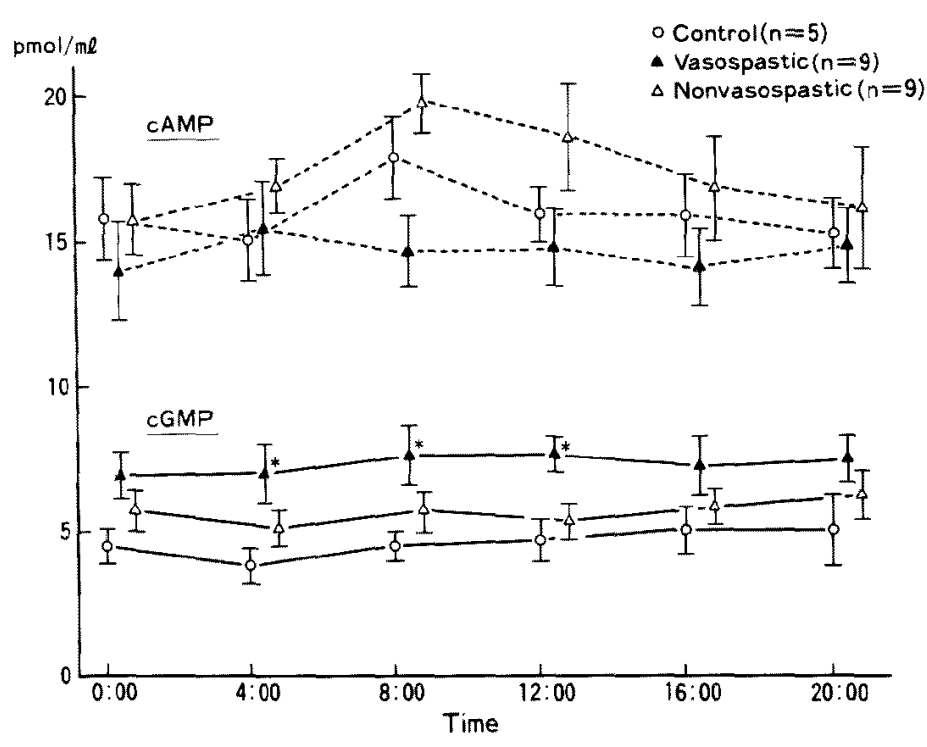

Fig. 1. Circadian variation of plasma cyclic nucleotides in control subjects and patients with vasospastic and nonvasospastic angina. $* p<0.05$ vs control subjects. $\quad$ AMP $=$ plasma cyclic AMP concentration $; \mathrm{cGMP}=$ plasma cyclic GMP concentration.

all groups, blood pressure and cardiac rate showed higher levels from noon to $8 \mathrm{p} . \mathrm{m}$. and lower levels from midnight to $4 \mathrm{a.m}$. (Table I).

2. Circadian variation of plasma cyclic nucleotides

No significant circadian variation of plasma cyclic AMP was observed among the 3 groups. Although the anginal groups showed a tendency toward higher plasma cyclic AMP, plasma cyclic GMP as an index of parasympathetic nerve activity showed significantly higher levels at 4 and 8 a.m. and noon in vasospastic patients when compared with those of the control group (Fig. 1).

3. Provocation of myocardial ischemia by pilocarpine

Patients refrained from taking breakfast and the pilocarpine test was carried out at 10 a.m. Chest pain and/or ischemic change on EGG induced by pilocarpine occurred in 17 of 19 patients with vasospastic angina and in 11 of 14 patients with nonvasospastic angina. These ischemic signs appeared from 7 to $25 \mathrm{~min}$ after the pilocarpine injection and were not related to the extent of parasympathetic signs such as sweating and salivation. Plasma concentration of norepinephrine $15 \mathrm{~min}$ after administration of pilocarpine was increased by $63 \%$ (from $229.3 \pm 24.9 \mathrm{pg} / \mathrm{ml}$ to $374.9 \pm 40.4 \mathrm{pg} / \mathrm{ml}$ ) in controls and by $106 \%$ (from $286.0 \pm 24.5 \mathrm{pg} / \mathrm{ml}$ to $590.0 \pm 49.4 \mathrm{pg} / \mathrm{ml}$ ) in patients with vasospastic angina $(p<0.02$ vs control). Such significant in- 
Table II. Effect of Pilocarpine on the Variation of Plasma Catecholamine Concentration in Control Subjects and Patients with Angina Pectoris

Plasma norepinephrine concentration $(\mathrm{pg} / \mathrm{ml})$

\begin{tabular}{|c|c|c|c|c|c|}
\hline Time (min) & 0 & 15 & 30 & 60 & 90 \\
\hline $\begin{array}{l}\text { Control subjects } \\
\quad(n=7)\end{array}$ & $\begin{array}{r}229.3 \\
\pm 24.9\end{array}$ & $\begin{array}{r}374.9 \\
\pm 40.4\end{array}$ & $\begin{array}{r}343.5 \\
\pm 28.0\end{array}$ & $\begin{array}{r}320.8 \\
\pm 35.1\end{array}$ & $\begin{array}{r}286.4 \\
\pm 24.3\end{array}$ \\
\hline $\begin{array}{l}\text { Vasospastic angina } \\
\qquad(\mathrm{n}=16)\end{array}$ & $\begin{array}{r}286.0 \\
\pm 24.5\end{array}$ & $\begin{array}{l}590.0 \\
\pm 49.4 * *\end{array}$ & $\begin{array}{l}565.9 \\
\pm 52.8 * *\end{array}$ & $\begin{array}{l}498.4 \\
\pm 55.2 *\end{array}$ & $\begin{array}{r}431.7 \\
\pm 58.0\end{array}$ \\
\hline $\begin{array}{l}\text { Nonvasospastic angina } \\
(\mathrm{n}=14)\end{array}$ & $\begin{array}{r}243.6 \\
\pm 27.2\end{array}$ & $\begin{array}{r}426.0 \\
\pm 42.8\end{array}$ & $\begin{array}{r}436.2 \\
\pm 49.7\end{array}$ & $\begin{array}{r}404.0 \\
\pm 36.4\end{array}$ & $\begin{array}{r}384.7 \\
\pm 34.5\end{array}$ \\
\hline
\end{tabular}

Plasma epinephrine concentration $(\mathrm{pg} / \mathrm{ml})$

\begin{tabular}{c|c|c|c|c|c}
\hline Time (min) & 0 & 15 & 30 & 60 & 90 \\
\hline $\begin{array}{c}\text { Control subjects } \\
(\mathrm{n}=7)\end{array}$ & $\begin{array}{r}96.9 \\
\pm 10.9\end{array}$ & $\begin{array}{r}94.1 \\
\pm 13.1\end{array}$ & $\begin{array}{r}98.0 \\
\pm 10.3\end{array}$ & $\begin{array}{r}86.8 \\
\pm 11.8\end{array}$ & $\begin{array}{r}107.4 \\
\pm 20.3\end{array}$ \\
\hline $\begin{aligned} \text { Vasospastic angina } \\
(\mathrm{n}=16)\end{aligned}$ & $\begin{array}{r}123.4 \\
\pm 14.0\end{array}$ & $\begin{array}{c}198.3 \\
\pm 15.7 * * *\end{array}$ & $\begin{array}{c}168.9 \\
\pm 17.3 * *\end{array}$ & $\begin{array}{r}173.2 \\
\pm 28.0 *\end{array}$ & $\begin{array}{r}164.8 \\
\pm 27.2\end{array}$ \\
\hline $\begin{array}{c}\text { Nonvasospastic angina } \\
(\mathrm{n}=14)\end{array}$ & $\begin{array}{r}97.1 \\
16.0\end{array}$ & $\begin{array}{c}151.1 \\
\pm 25.2\end{array}$ & $\begin{array}{r}161.9 \\
\pm 28.6\end{array}$ & $\begin{array}{r}149.9 \\
\pm 26.0\end{array}$ & $\begin{array}{r}167.9 \\
\pm 29.3\end{array}$
\end{tabular}

Values are given as mean \pm 1 SEM. ${ }^{* * *} \mathrm{p}<0.01,{ }^{* *} \mathrm{p}<0.02, * \mathrm{p}<0.05$ vs control subjects.

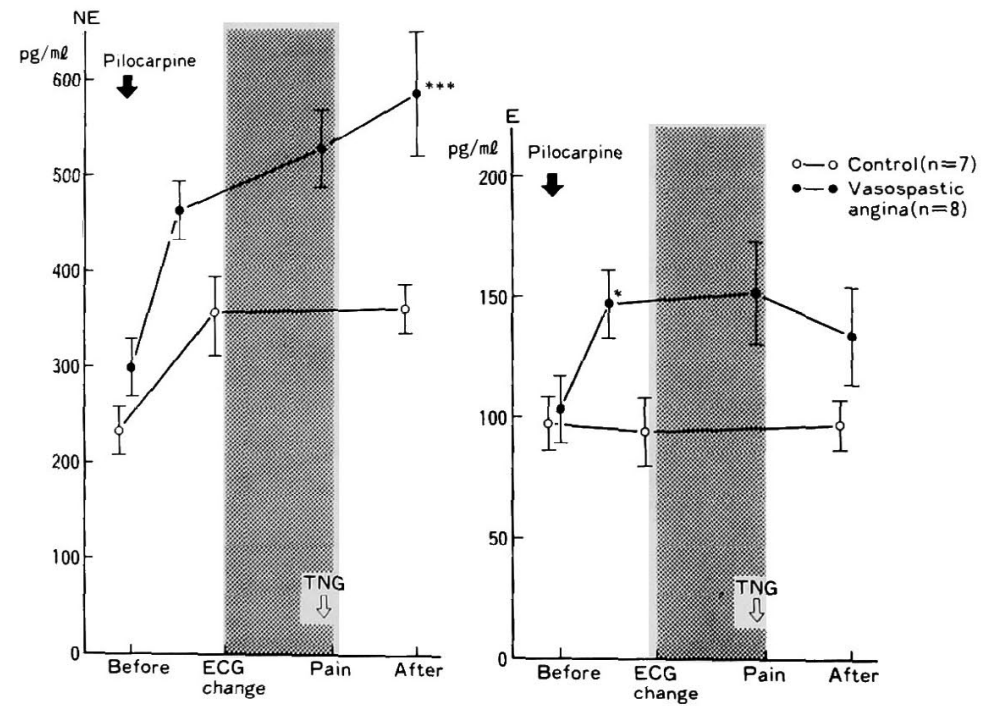

Fig. 2. Effect of pilocarpine on the variation of plasma catecholamine concentration in control subjects and patients with vasospastic angina. $* * * p<0.01, * p<0.05$ vs control subjects. $N E=$ plasma norepinephrine concentration; $\mathrm{E}=$ plasma epinephrine concentration; $\mathrm{TNG}=$ sublingual administration of nitroglycerin. 
creases were noticed also at 30 and $60 \mathrm{~min}$ in patients with vasospastic angina. Plasma epinephrine showed no response to pilocarpine in control subjects, but it was increased by $61 \%$ and $56 \%$ (from $123.4 \pm 14.0 \mathrm{pg} / \mathrm{ml}$ to $198.3 \pm$ $15.7 \mathrm{pg} / \mathrm{ml}$ and from $97.1 \pm 16.0 \mathrm{pg} / \mathrm{ml}$ to $151.1 \pm 25.2 \mathrm{pg} / \mathrm{ml}$ ) at $15 \mathrm{~min}$ in vasospastic and nonvasospastic anginal patients, respectively. These increases were still present $90 \mathrm{~min}$ after the pilocarpine injection (Table II). A marked rise in plasma norepinephrine and epinephrine concentrations preceded the occurrence of chest pain and/or EGG changes in 8 cases with variant angina

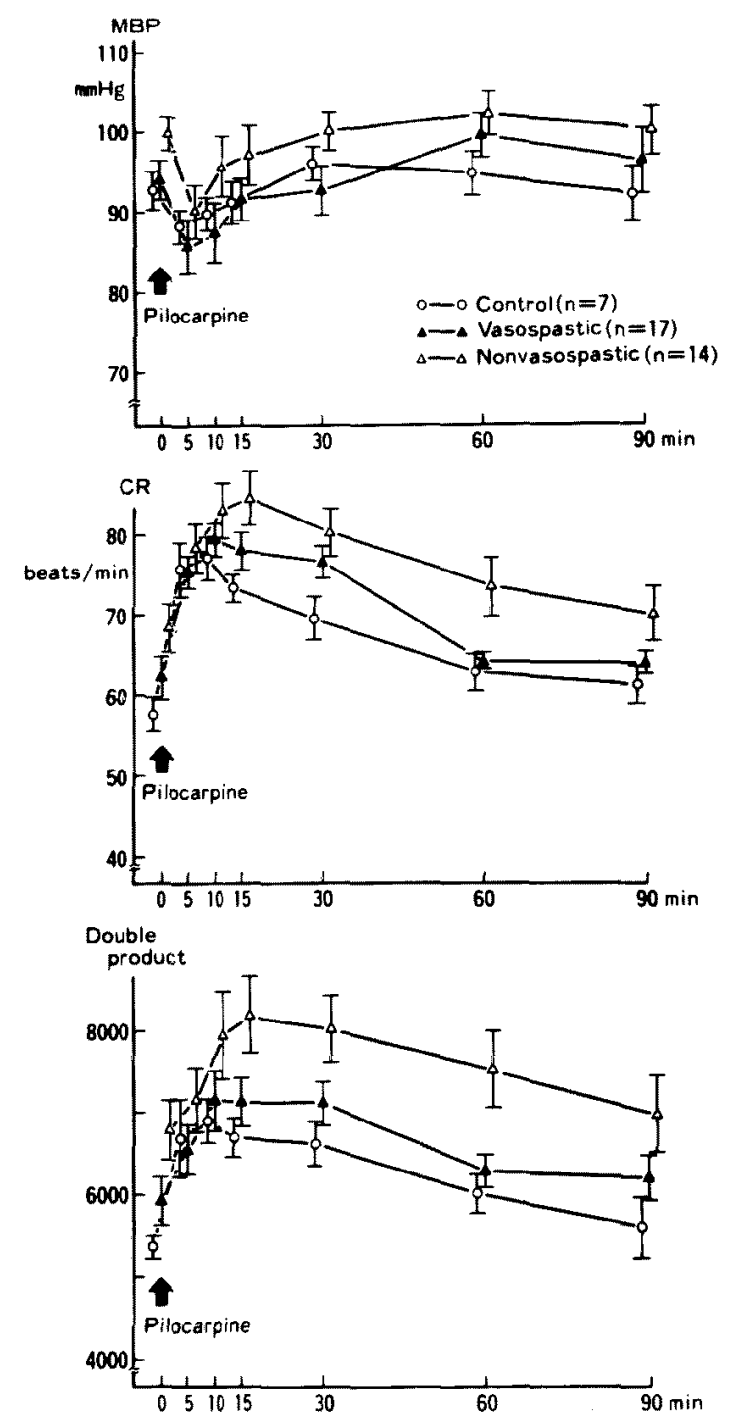

Fig. 3. Effect of pilocarpine on mean blood pressure (MBP), cardiac rate (CR) and double product in control subjects and patients with vasospastic and nonvasospastic angina. 
in whom blood sampling was performed before and during the onset of ischemic signs induced by the pilocarpine test (Fig. 2).

Plasma cyclic AMP concentration was increased by $30 \%$ (from $17.5 \pm$ $1.1 \mathrm{pmol} / \mathrm{ml}$ to $22.7 \pm 1.6 \mathrm{pmol} / \mathrm{ml}$ ) in 27 patients with angina pectoris $30 \mathrm{~min}$ after the pilocarpine injection. Although the increase in cyclic AMP concentration decreased to the initial level at $90 \mathrm{~min}$ in control subjects, this recovery was markedly delayed in patients with angina pectoris. Cyclic GMP concentrations were also increased by $86 \%$ and $76 \%$ (from $4.3 \pm 1.0 \mathrm{pmol} / \mathrm{ml}$ to $8.0 \pm 1.3 \mathrm{pmol} / \mathrm{ml}$ and from $5.8 \pm 0.6 \mathrm{pmol} / \mathrm{ml}$ to $10.2 \pm 1.1 \mathrm{pmol} / \mathrm{ml}$ ) in both control subjects and anginal patients at $30 \mathrm{~min}$ after the pilocarpine injection, respectively. There was no significant difference of cyclic nucleotide levels between patients with nonvasospastic and vasospastic angina.

4. Hemodynamic responses during the pilocarpine test

No differences in the extent of the increase in blood pressure, cardiac rate and double product were observed among vasospastic, nonvasospastic and control groups, although initial levels of blood pressure and cardiac rate were higher in the vasospastic group in comparison with those of the controls (Fig. 3).

5. Presentation of one representative case

The case of H.K., age 55 years, who had recurrent attacks of chest pain associated with transient ST-segment elevation is shown in Fig. 4. Several blood samples were obtained before, during and after the spontaneous attacks which occurred at 4:30, 7:00, 10:50, 11:10 and 11:25 p.m. Plasma norepinephrine and epinephrine concentrations were already increased $10 \mathrm{~min}$

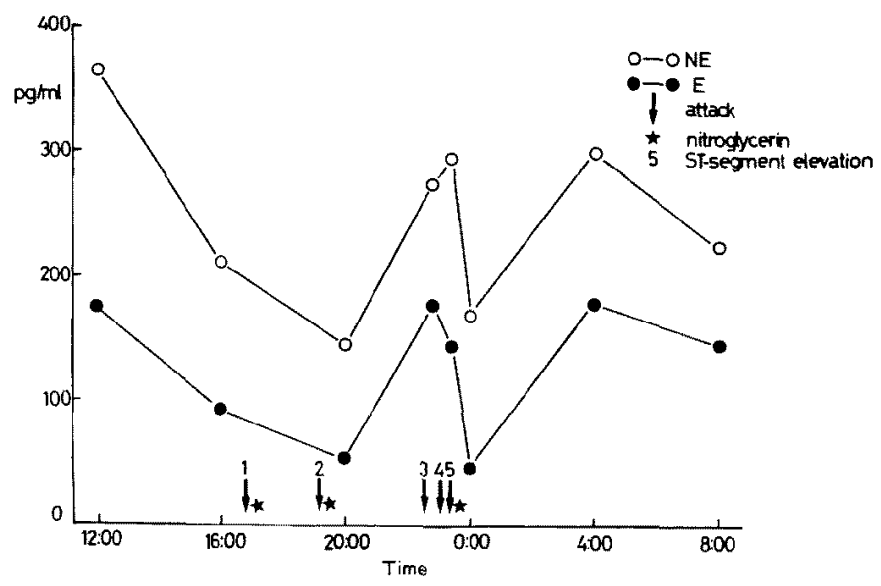

Fig. 4. Circadian variation of plasma catecholamine concentration and these changes before, during and after spontaneous anginal attacks in a case of H.K. (55 years) with vasospastic angina. NE= plasma norepinephrine concentration; $\mathbf{E}=$ plasma epinephrine concentration. 


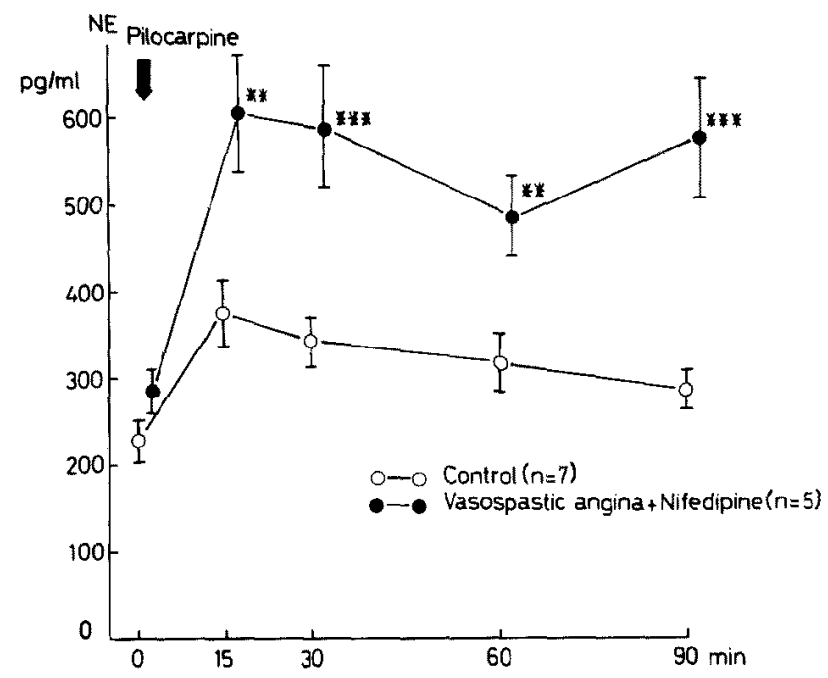

Fig. 5. Effect of pilocarpine on plasma norepinephrine concentration in control subjects and patients with vasospastic angina after the pretreatment of nifedipine. $* * * \mathrm{p}<0.01, * * \mathrm{p}<0.02$. NE= plasma norepinephrine concentration.

before the spontaneous attack at 11:10 p.m. and reached a maximum at 11:25 p.m. during the attack. Marked ST-segment elevation in the chest leads was observed at 11:25 p.m. (Fig. 4).

6. Autonomic activity during suppression of anginal attacks with nifedipine

To investigate whether hyperactivity of the sympathetic nervous system is a primary factor related to the mechanism of anginal episodes or if myocardial ischemia results in a rise of sympathetic nerve tone, nifedipine (10$20 \mathrm{mg}$ ) was administered orally 1 hour prior to the pilocarpine test to 5 patients with vasospastic angina and to 7 control subjects. After confirming the suppression of the occurrence of spontaneous anginal attacks and ECG changes by nifedipine treatment, the pilocarpine test was performed. No anginal attacks or EGG changes were induced by the pilocarpine test in these anginal patients; nevertheless, hyperresponses of plasma norepinephrine were still observed (Fig. 5).

\section{DisGussion}

It is strongly suggested that autonomic nervous system dysfunction, among many possible causes proposed currently, contributes to the initiation of coronary vasospasm. ${ }^{1)-3)}$ In the present study, vasospastic patients had greater circadian variations of plasma catecholamine levels and enhanced 
pharmacologic responses of the sympathetic nervous system in comparison with those of control subjects. These increases in plasma catecholamines preceded the occurrence of chest pain and/or ischemic ECG changes in both spontaneous and pilocarpine induced anginal attacks. Although nifedipine, a calcium channel blocking agent, completely suppressed chest pain and ischemic ECG changes, these high plasma catecholamine levels and hypcrresponsiveness of the sympathetic nervous system pcrsisted. These results suggest that the higher responsiveness in the sympathetic nervous system is the cause rather than the consequence of transient myocardial ischemia in patients with vasospastic angina. In particular, the rise in plasma catecholamines in samples drawn prior to spontaneous and pilocarpine induced anginal attacks plays an important role in confirming this hypothesis. Our study supports Yasue's hypothesis that coronary spasm can be provoked by simulation of $\alpha$-adrenergic receptors present in the large coronary arteries in patients with hyperactive parasympathetic nervous systems. It was previously reported that plasma norepinephrine levels in the resting state were higher in patients with angina pectoris than that in normal subjects. ${ }^{71-9)}$ In contrast to our observation, Robertson reported that peripheral venous norepinephrine concentrations at rest and functional testing of the sympathetic nervous system in patients with vasospastic angina did not differ from those in control subjects. ${ }^{10}$ There have not as yet been many studies which examine autonomic nerve activity in vasospastic angina. Further accumulation of data which detect precise changes in plasma catecholamine levels before, during and after spontaneous episodes of vasospastic angina will be needed to elucidate the role of the autonomic nervous system in the initiation of vasospastic angina.

Although sympathetic hyperactivity seems to be one of the important mechanisms responsible for coronary vasospasm, its role is still controversial. The sympathetic and parasympathetic innervation to the heart are very close to each other and arise mostly from the cervical region. Accordingly localized sympathetic activity plays an important role in inducing coronary vasospasm. Therefore, cadiac sympathetic denervation might be a reasonable approach in the prevention of coronary vasospasm. Recent studies have indicated that cardiac denervation prevents recurrent vasospastic activity in variant angina. However, it is conceivable that cardiac sympathetic denervation leads to interruption of pain fibers, resulting in symptomatic relief rather than the abolition of coronary spasm, because the angiographic demonstration of occlusive coronary spasm remains. ${ }^{4,11)}$ Furthermore, the arterial-coronary sinus differences in plasma norepinephrine concentrations were measured to assess the localized sympathetic activity in the coronary arteries; however, no significant difference was obscrved. ${ }^{10}$ ) This suggests that the arterial- 
coronary sinus difference in plasma norepinephrine is not reflected in the circulating catecholamine levels because of a relatively small release of catecholamine due to localized sympathetic nerve activity as compared with circulating catecholamine concentration. However, the coronary artery tonus in patients with vasospastic angina is increased early in the morning when sympathetic activity is low and is decreased in the afternoon when sympathetic activity increases. ${ }^{12}$ Thus, the enhanced generalized sympathetic nervous system activity does not appear to be the only mechanism of coronary vasospasm.

To evaluate the role of the parasympathetic nervous system in vasospastic angina is important; however, while plasma catecholamine and cyclic AMP concentrations are generally accepted to reflect the activity of the sympathetic nervous system, there is not necessarily an appropriate index for assessing the activity of the parasympathetic nervous system. One recent report suggested that plasma cyclic GMP concentrations might possibly reflect parasympathetic nerve activity, since in fasted rats the cholinergic agents methacholine or acetylcholine with physostigmine caused a rapid increase in plasma cyclic GMP concentration, and these cholinergic agents failed to increase plasma cyclic GMP following pretreatment with atropine. ${ }^{13 !}$ In other reports, electrical stimulation of the vagal nerve increased the arterial and plasma levels of cyclic GMP accompanied by a decrease in heart rate in rabbits, and these increases in arterial and plasma cyclic GMP were significantly prevented by pretreatment with atropine. ${ }^{14), 15)}$ Furthermore, plasma cyclic GMP concentration rose markedly in response to an infusion of the $\alpha$-adrenergic agent norepinephrine which led to activation of the parasympathetic nervous system through the baroreceptor-reflex, as indicated by the raised blood pressure and resultant bradycardia, and an increase in plasma cyclic GMP level was distinctly blocked by atropine. ${ }^{16), 17)}$ Thus, it was strongly suggested that parasympathetic nerve activity could be reflected by plasma cyclic GMP levels. Therefore, plasma cyclic GMP concentration was determined in this study to assess parasympathetic nerve activity.

Basal levels of plasma cyclic GMP, as an index of parasympathetic nerve activity, in patients with vasospastic angina were significantly higher than those in control subjects and hyperresponse of plasma cyclic GMP was observed during pilocarpine induced anginal attacks. Since pilocarpine induces norepinephrine release from the postganglionic sympathetic nerve terminals in the heart, one of the coronary vasospastic effects of pilocarpine may be due to the activation of $\alpha$-receptors in large coronary arteries with the release of norepinephrine. On the other hand, Toda reported that acetylcholine, which is the neurotransmitter of the parasympathetic nervous 
system and has a vasodilating action on the isolated coronary artery in experimental animals, caused contraction of human epicardial coronary arteries in herical strips, and atropine suppressed these responses. The report suggests that the contraction of the human coronary artcries may be mediated by muscarinic receptors. ${ }^{18)}$ Thus, the parasympathetic nervous system is likely to be involved in the mechanisms of coronary vasospasmi If the increase in sympathetic nerve activity is a major cause of coronary vasospasm, anginal episodes should occur in the daytime. However, vasospastic angina, in fact, usually occurs early in the morning, when myocardial oxygen consumption is lower than later in the day. In a previous report, it was proposed that the REM (rapid eye movement) period, which is considered to be a period of marked imbalance of sympathetic and parasympathetic nerve activity, had a close relation to vasospastic anginal attacks. ${ }^{19)}$ It is thus highly probable that both sympathetic and parasympathetic nerve activities play important roles in the production of coronary vasospasm.

This study will be submitted by Dr. Kazuhiko Tamada as a thesis for the degree of Doctor of Medical Science, Kobe University School of Medicine.

\section{AcknowledGments}

The authors express their gratitude to Professor Yasuyuki Ueba, Dr. Eisaku Komoto, Dr. Toshiyuki Miyazaki and Dr. Junko Sasaki for their valuable help and suggestions.

\section{REFERENCES}

1. Yasue H, Touyama M, Shimamoto M, Kato H, Tanaka S, Akiyama F: Role of autonomic nervous system in the pathogenesis of Prinzmetal's variant form of angina. Circulation 50: 534,1974

2. Torii S, Araki H, Sora T, Kakimaru Y, Kanatani H, Naito S, Nakagaki K: Provocation of anginal attacks by pilocarpine injection. Heart 6: 338, 1974 (in Japanese)

3. Endo M, Hirosawa K, Kaneko N, Hase K, Inoue Y, Konno S: Prinzmetal's variant angina. Coronary arteriogram and ventriculogram during attack induced by methacholine. New Engl J Mcd 294: 252, 1976

4. Clark DA, Quint RA, Mitchell Rl, Angell WW: Coronary artery spasm. Medical management, surgical denervation, and autotransplantation. J Thorac Cardiovasc Surg 73: 332, 1977

5. Komoto E, Tamada K, Sasaki J, Miyazaki T, Kujime K, Ito Y, Ueba Y, Nagai I: Plasma catecholamine assay using an electrochemical detector (Voltanmetry). Ann Kobe Univ Health Res Inst 9: 48, 1984

6. Honma M, Satoh T, Takezawa J, Ui M: An ultrasensitive method for the simultaneous determination of cyclic AMP and cyclic GMP in small volume samples from blood and tissue. Biochem Med 18: 257, 1977

7. Costello RB, DiBianco R, Singh S, Gottdiener JS, Cockrell J, Fletcher RD: Plasma catecholamines at rest and peak exercise in patients with chronic angina. Circulation 62: III-125, 1980 
8. Battock DJ, Alvarez H, Chidsey CA: Effects of propranolol and isosorbide dinitrate on exercise performance and adrenergic activity in patients with angina pectoris. Circulation 39 : 157,1969

9. Schwartz L, Sole MJ, Vaughan-Neil EF, Hussain NM: Catecholamines in coronary sinus and peripheral plasma during pacing induced angina in man. Circulation 51: 37, 1979

10. Robertson RM, Bernard Y, Robertson D: Arterial and coronary sinus catecholamines in the course of spontaneous coronary artery spasm. Am Heart J 105: 901, 1983

11. Amadeo Betriu, Pomar JL, Bourassa MG, Grondin CM: Influence of partial sympathetic denervation on the results of myocardial revascularization in variant angina. Am J Cardiol 51: 661,1983

12. Yasue F, Omote S, Takizawa A, Nagao M, Miwa K, Tanaka S: Circadian variation of exercise capacity in patients with Prinzmetal's variant angina. Role of exercise-induced coronary arterial spasm. Circulation 59: 938, 1979

13. Honma M, Ui M: Plasma cyclic GMP. Response to cholinergic agents. Eur J Pharmacol 47: 1,1978

14. Fink GD, Paddock RJ, Rodgers GM, Busttil RW, George WJ: Elevated cyclic GMP levels in rabbit atria following vagal stimulation and acetylcholine treatment. Proc Soc Exp Biol Med 153: 78, 1976

15. Tamada K, Sasaki J, Miyazaki T, Komoto E, Ito Y, Fukuzaki H, Ueba Y: Autonomic response to pilocarpine administration in patients with angina pectoris. Respiration and Circulation 31 : 1187, 1983 (in Japanese)

16. Ball JH, Kaminsky NI, Hardman JG, Broadus AE, Sutherland EW, Liddle GW: Effects of catecholamines and adrenergic blocking agents on plasma and urinary cyclic nucleotides in man. J Clin Invest 51: 2124, 1972

17. Suematsu M, Kotake C, Tamada K, Sasaki J, Kujime K, Ito Y, Ueba Y, Fukuzaki H: R-R interval variations as a parameter of the parasympathetic nerve activity (abstr). Jpn Girc J 48: 942,1984

18. Toda N: Isolated human coronary arteries in response to vasoconstriction substances. Am J Physiol 245: H937, 1983

19. Nowlin JB, Troyer WG, Collins WS, Silverman G, Nichols CR, McIntosh HD, Estes EH, Bogdonoff MD: The association of nocturnal angina pectoris with dreaming. Ann Int Med 63: 1040,1965 